\title{
Synthesis and Analysis of Properties of an Immunogenic Fragment from NS4A Polypeptide of Hepatitis C Virus
}

\author{
A. N. Belyavtsev ${ }^{a, b}, 1$, M. V. Melnikovac ${ }^{c}$ N. G. Shevchenko ${ }^{b, d}$, G. V. Sapronov ${ }^{d}$, \\ R. G. Vahrenev ${ }^{c}$, N. S. Shastina ${ }^{a}$, E. F. Kolesanova ${ }^{c}$, and L. I. Nikolaeva ${ }^{b}$ \\ ${ }^{a}$ Lomonosov Institute of Fine Chemical Technologies, MIREA-Russian Technological University, Moscow, 119571 Russia \\ ${ }^{b}$ Gamaleya National Research Center for Epidemiology and Microbiology, Moscow, 123098 Russia \\ ${ }^{c}$ Institute of Biomedical Chemistry, Moscow, 119121 Russia \\ ${ }^{d}$ Russian Medical Academy of Continuous Professional Education, Moscow, 123995 Russia \\ Received July 13, 2020; revised July 25, 2020; accepted July 27, 2020
}

\begin{abstract}
The work is aimed at the synthesis and analysis from NS4A of hepatitis C virus (HCV) antigen peptide fragment that contains a conserved B-cell and T-helper epitopes. The 24-mer peptide VIVGRIILSGRPAVIPDREVLYRK-NH2, which contains the main immunogenic site 24-46 of HCV NS4A antigen (corresponding to the 1681-1703 amino acid residues of the HCV polypeptide), subtype $1 \mathrm{~b}$, has been prepared via solid-phase synthesis according to the Fmoc-protocol. Particles with diameters of $73 \pm 10 \mathrm{~nm}(30 \%)$ and $236 \pm 5 \mathrm{~nm}(70 \%)$ have been detected in the water solution of the highly purified peptide $(0.5 \mathrm{mg} / \mathrm{mL}) \mathrm{by}$ dynamic light scattering. The polydispersity index of $0.377 \pm 0.012$ implies the existence of heterogeneity because of the aggregation of the peptide molecules. The $\zeta$-potential of the peptide aggregates has been determined as $7.0 \pm 0.5 \mathrm{mV}$ by means of electrophoretic light scattering. These data confirm the possibility for the development of a nanoscale liposome form of the peptide preparation. Immunoreactivity of the synthesized highly purified peptide has been studied with the use of blood sera of patients with chronic hepatitis C. Antipeptide immunoglobulins $G$ have been detected in $41.7 \%$ of serum samples. Thus, this peptide has been shown to reproduce at least one B-epitope, to which antibodies are raised during natural HCV infection. The synthesized 24-mer peptide is a promising candidate for further research and for use as a potential immunogen for the design of a nanoscale therapeutic immunogenic liposomal peptide composition with synthetic lipids as an adjuvant.
\end{abstract}

Keywords: hepatitis C, NS4A antigen, synthetic peptide, solid-phase peptide synthesis, physicochemical properties of peptide, immunoreactivity

DOI: $10.1134 / \mathrm{S} 1068162021030031$

\section{INTRODUCTION}

The development of antiviral therapy for hepatitis $\mathrm{C}$ and a vaccine against hepatitis $\mathrm{C}$ virus $(\mathrm{HCV})$ is one of the urgent tasks of public healthcare. Currently, researchers continue to search for new drugs or to modify existing drugs to increase the effectiveness or minimize side effects [1-4]. Synthetic peptides containing amino acid sequences of antigen epitopes can purposefully activate cells of the immune system [58]. To create a proper immunogen, it is necessary to use a peptide containing not only a B-cell antigenic determinant, but also a T-helper epitope, as well as a properly selected adjuvant, which will increase immunogenicity and form immunological memory [6, 8-13].

Abbreviations: HCV, hepatitis C virus; SVR, sustained virological response; Fmoc, 9-fluorenylmethyloxycarbonyl; NF-KB, nuclear factor kappa B; NS4A, nonstructural protein 4A.

${ }^{1}$ Corresponding author: phone: +7 (903) 265-39-83; e-mail: belyavcev@mirea.ru.
In this work, of HCV NS4A polypeptide (subtype 1b) was chosen as the object of research, since this subtype is the most widespread in Russia. The biological significance of the polypeptide lies in the fact that it acts as a cofactor of the HCV NS3 serine protease, activating the latter by changing its conformation in the region of the catalytic triad during the formation of a complex with NS4A polypeptide. As a result, the catalytic triad His-1083, Asp-1107, and Ser-1165 interacts with the substrate and thereby accelerates the cleavage of the nonstructural proteins NS4B, NS5A, and NS5B from the viral polyprotein [14]. The NS4A polypeptide consists of 54 amino acid residues (corresponding to amino acid residues 1658-1711 of the HCV polyprotein sequence) and contains experimentally confirmed B-cell and T-helper (stimulating $\mathrm{CD}^{+}-\mathrm{T}$ cells) epitopes $[15,16]$. The $\mathrm{N}$-terminal region of the NS4A polypeptide is hydrophobic and immersed in the lipid bilayer of the membrane of the endoplasmic reticulum; as a result the NS3 protein 


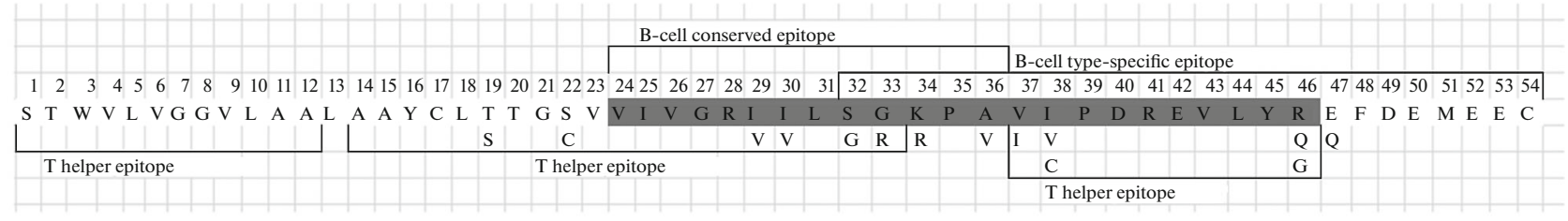

Fig. 1. Amino acid sequence of NS4A antigen of hepatitis C virus subtype $1 \mathrm{~b}$. Under the sequence are the designations of amino acid substitutions in other isolates of subtype $1 \mathrm{~b}$ [24]. The region 24-46 amino acid residues selected for peptide synthesis is highlighted in gray.

containing protease and helicase domains is retained near the membrane [17]. The NS4A polypeptide is also involved in blocking intracellular antiviral signaling, regulation of viral replication, and hyperphosphorylation of the NS5A antigen [18]. The NS3NS4A protease complex is involved in the assembly of the virion, and its mutations can lead to assembly defects [19]. It is assumed that the NS4A polypeptide promotes the participation of creatine kinase B in the functioning of the HCV replication complex, which leads to an increase in the ATP level and stimulation of enzymatic activities necessary for replication [20]. In accordance with a hypothetical model of molecular interactions between NS3, NS4A, and NS5A, the polyprotein region 1691-1704 aa, corresponding to NS4A 34-47 aa, is of particular importance in providing these contacts [21]. NS4A fragment 21-34 aa (corresponding to 1678-1691 amino acid residues of HCV polyprotein) directly interacts with the NS3 protein in a special region that binds the serine protease cofactor, and contains a region conserved for all viral genotypes (Fig. 1) [16, 21]. Blockage of the corresponding regions of the NS4A polypeptide may have an inhibitory effect on the replication activity of the virus. One of the ways of such blocking is binding to antibodies specific to the site of interaction of the NS4A polypeptide with the NS3 protease domain. For the production of such antibodies, it is necessary to formulate an immunogenic construct containing both the NS4A polypeptide region responsible for interaction with the NS3 protease and the B-cell and Thelper epitopes [6, 8, 12]. Since the NS4A polypeptide contains experimentally identified B-cell and T-helper epitopes, which are fully or partially included in the site of interaction with NS3 [15, 16], the immunogenic construct can be a fragment of the NS4A polypeptide containing both the site of interaction with NS3, and the indicated epitopes. It has been shown that high titers of antibodies to the NS4A polypeptide are a prognostic sign of the effectiveness of hepatitis $\mathrm{C}$ treatment [22, 23].

The aim of this work is to synthesize a 24-mer peptide fragment, containing conserved $\mathrm{B}$-cell and T-helper epitopes from NS4A antigen of hepatitis C virus subtype $1 \mathrm{~b}$, as well as the NS3 protease interaction site, with subsequent analysis of the physico- chemical properties of this peptide and assessment of immunoreactivity.

\section{RESULTS AND DISCUSSION}

After analyzing the literature data, a 23-mer fragment VIVGRIILSGRPAVIPDREVLYR corresponding to 1681-1703 amino acid sequence of HCV polyprotein of subtype $1 \mathrm{~b}$ was selected for synthesis [24]. This fragment contains most of the NS4A binding site with the serine protease NS3, full B-cell (conserved for all genotypes, 24-36 aa) [16] and T-helper epitopes (37-46 aa) [15], as well as a partially type-specific Bcell (32-54 amino acid residues) [25] and T-helper epitopes (14-33 aa) [26] (Fig. 1).

The selected fragment was synthesized as amidated at the $C$-end of the 24-mer peptide VIVGRIILSGRPAVIPDREVLYRK-NH ${ }_{2}(M=2719 \mathrm{~g} / \mathrm{mol})$. Amidation of the $C$-terminal residue of the peptide simulates its natural state which is participation in an amide (peptide) bond with a neighboring amino acid [27]. The presence of lysine allows this peptide to be acylated at its less hydrophobic $C$-terminus with a lipophilic adjuvant through the $\varepsilon$-amino group of lysine, provided it is blocked by a selectively removable protective group. The peptide was obtained by solid-phase synthesis on Rink amide resin according to the Fmoc protocol by the method of in situ activated esters [28, 29]. After synthesis, the peptide was purified by reversed phase high-performance liquid chromatography (RP-HPLC) using UV and mass-spectrometric detection to identify the target peptide and impurities. The purity of the obtained peptide preparation was more than $95 \%$ according to the data of analytical HPLC (Fig. 2).

To confirm the reproduction of B-epitopes, the immunoreactivity of the purified peptide was assessed by the method of enzyme-linked immunosorbent assay (ELISA) using blood sera from people infected with hepatitis $C$ virus. Eighty-four blood serum samples from people infected with HCV were examined. According to the results of ELISA in the "Best-antiHCV-spectrum" test system, it was found that these samples contained antibodies to the full-size NS4A and NS4B antigens. As a control, serum samples from 10 healthy people were tested, in which anti-HCV antibodies were absent. 


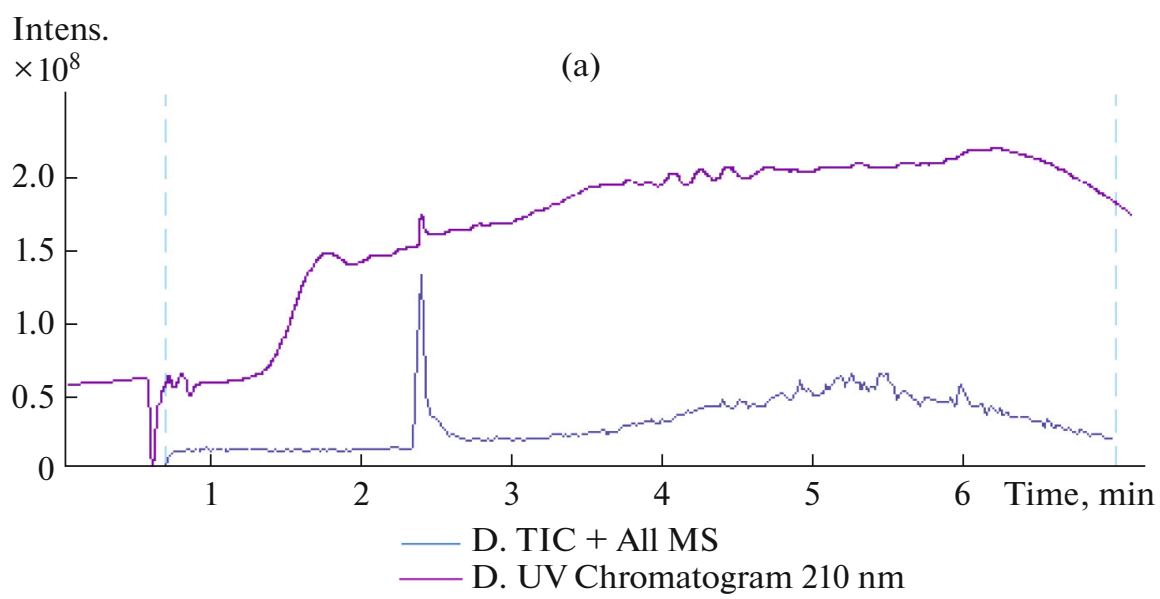

Intens.

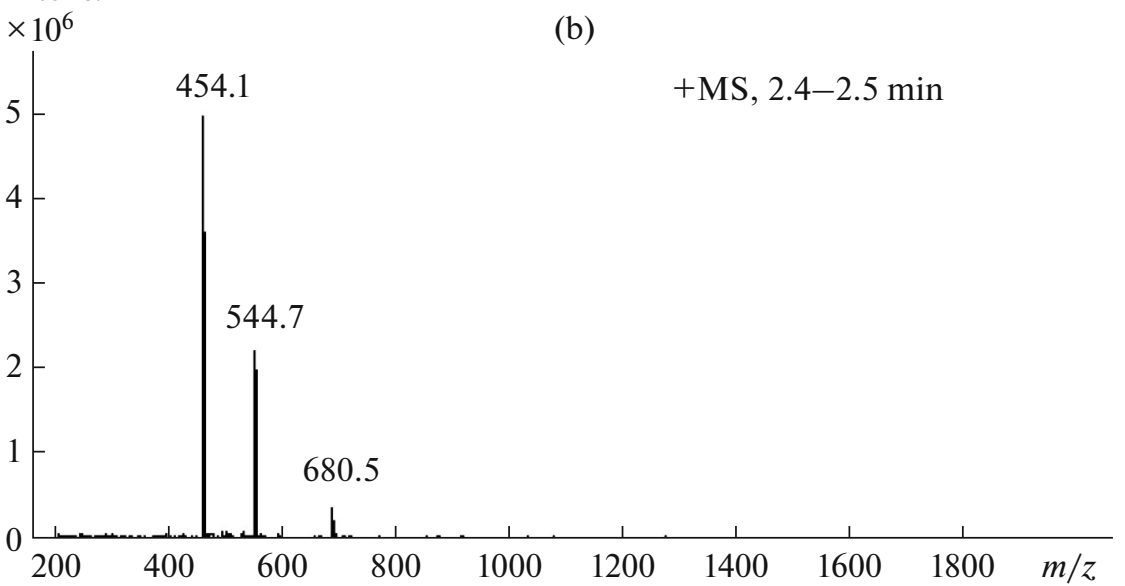

Fig. 2. (a) Chromatogram of HPLC of a 24-membered peptide after preparative purification; (b) mass spectrum of the purified peptide, 4-, 5- and 6-charged ions are presented.

Antibodies to the synthesized peptide were detected by ELISA in the blood sera of $41.7 \%$ of infected patients. Antibodies to this peptide were not detected in all 10 blood serum samples from healthy people. In positive samples from infected patients, the excess of the optical density (OD) relative to the average value of the OD of samples from healthy people ranged from 2.5 to 159 times. However, most of the positive serum samples $(68.57 \%)$ had a low positivity rate (PR) of antibodies, from 1 to 10 . (PR is the ratio of the OD of a serum sample to the OD threshold). The share of positive samples with a high PR (from 21 to 53 ) was $22.86 \%$. Earlier analysis of chronic hepatitis $\mathrm{C}$ patients sera demonstrated the proportion of NS4Apositive samples equal to $45 \%$ (with recombinant NS4A, reproduced 19-54 amino acid residues of NS4A, as an antigen) [30, 31], which suggests the presence of at least one immunodominant B-epitope of the NS4A polypeptide, to which antibodies are formed during $\mathrm{HCV}$ infection, inside the synthesized peptide.
Among 84 serum samples from infected individuals, 59 serum samples were obtained from patients prior to initiation of antiviral therapy with pegylated interferon- $\alpha 2$ and ribavirin. Considering the completion of treatment and its result, the sera were divided into two groups. The first group of sera included 29 samples from patients with a successful treatment result (sustained virological response (SVR) was achieved, i.e., RNA was not detected at 24 weeks after treatment); the second group of sera composed of 30 samples from patients who did not achieve SVR. In 20 patients $(66.7 \%)$ who did not achieve SVR, antibodies to the peptide were absent. Antipeptide immunoglobulins were not detected in 14 participants (48.3\%) who achieved SVR. There were no significant differences in the absence of antibodies between the groups ( $p>0.05 ; t=1.43)$, which is most likely due to the small number of compared samples. However, there is a clear tendency towards the presence of association between the antibodies to the selected fragment of NS4A polypeptide and SVR on interferon therapy. This additionally confirms the presence of the main B epitope(s) of the HCV NS4A polypeptide in 
the peptide we synthesized, since it has been shown that the presence of antibodies against this protein is a prognostic sign of successful interferon therapy $[22,23]$.

The presence of particles with sizes $73 \pm 10 \mathrm{~nm}$ $(30 \%)$ and $236 \pm 5 \mathrm{~nm}(70 \%)$ was shown in the peptide solution with the concentration of $0.5 \mathrm{mg} / \mathrm{mL}$ by dynamic light scattering. The polydispersity index of $0.377 \pm 0.012$ suggests the presence of heterogeneity due to the aggregation of peptide molecules. The $\zeta$-potential of peptide aggregates, which was $7.0 \pm 0.5 \mathrm{mV}$, was determined by electrophoretic light scattering. The apparently hydrophobic N-terminal region of the peptide facilitates the aggregation of its molecules, considering the relatively low solubility of the peptide in aqueous solution. These data confirm the possibility of developing a nanosized liposomal form of the peptide; its quite hydrophilic C-terminal region in liposomes will presumably be accessible for contact with Th-lymphocytes that will ensure an efficient preparation delivery $[32,33]$. It is known that lipophilic compounds based on fatty acids stimulate Tolllike receptors (nonspecific immune activation via NF$\kappa \mathrm{B}$-pathway) and act as effective adjuvants for synthetic peptides [34-37].

\section{EXPERIMENTAL}

We used Fmoc-protected L-amino acids Arg (Pbf) (Sigma-Aldrich, United States); Lys (Boc), Tyr $\left(\mathrm{OBu}^{t}\right)$, Leu, Val, Glu $\left(\mathrm{OBu}^{t}\right)$, Asp $\left(\mathrm{OBu}^{\mathrm{t}}\right)$, Pro, Ile, Ala, Gly, Ser $\left(\mathrm{OBu}^{\mathrm{t}}\right)$, Rink amide resin with Fmocprotection of the amino group (capacity $0.7 \mathrm{mmol} / \mathrm{g}$ ), $O$-(benzotriazol-1-yl)- $N, N, N^{\prime}, N^{\prime}$-tetramethyluronium hexafluorophosphate (HBTU) (Chempep, United States); 4-methylpiperidine, 1,8-diazabicyclo[5.4.0] undec-7-ene (DBU), triisopropylsilane, thioanisole, trifluoroacetic acid, 2,4,6-collidine, propionic anhydride (Acros Organics, Belgium); ethyl cyanohydroxyiminoacetate (Oxyma Pure) (Merck, Germany); potassium cyanide, ninhydrin, phenol (Warrington, UK); solvents dimethylformamide (DMF), methylene chloride, diethyl ether (Khimmed, Russia). Reagent grade DMF was additionally dried with freshly calcined 4A molecular sieves.

Preparation of the peptide VIVGRIILSGRPAVIPDREVLYRK- $\mathbf{N H}_{2}$. The synthesis was carried out manually in a glass reactor with a filter and a three-way stopcock for rinsing the resin; in the lower part of the reactor, an outlet for vacuum filtration is provided for removing excess reagents and rinsing the resin. At a synthesis scale of $0.25 \mathrm{mmol}$ (based on the number of active groups on the resin), $0.357 \mathrm{~g}$ of Rink resin (concentration of Fmoc- $\mathrm{NH}_{2}$-groups on the resin $0.7 \mathrm{mmol} / \mathrm{g}$ ), methylene chloride was added to swell the resin, the Fmoc-group was removed by the action of 4-methylpiperidine ( $2 \%, v / v$ hereinafter) and DBU (2\%) in DMF, then the peptide chain was extended, sequentially adding amino acids, removing the Fmoc group before adding the next amino acid. The carboxyl group of the attached amino acid was activated by HBTU and Oxyma Pure in the presence of 2,4,6-collidine in DMF. The formation of the peptide bond was carried out using a fourfold excess of the attached amino acid $(1 \mathrm{mmol})$. The resin was washed with $\operatorname{DMF}(5 \times 2 \mathrm{~mL})$ and methylene chloride $(3 \times 2 \mathrm{~mL})$.

The addition of amino acids was monitored using the Kaiser test. With a positive Kaiser test, the remaining reactive amino groups were acylated with propionic anhydride.

After cleavage from the resin with simultaneous removal of the side chain protecting groups by the action of trifluoroacetic acid $(92.5 \%)$ in the presence of thioanisole $(2.5 \%)$, triisopropylsilane $(2.5 \%)$, and water $(2.5 \%)$, the peptide was precipitated with diethyl ether. The peptide was purified by semipreparative HPLC on a YMC-Actus Triart C8 column (YMC, Switzerland; $250 \times 20 \mathrm{~mm}$ ID, $\mathrm{S}-5 \mu \mathrm{m}, 12 \mathrm{~nm}$ ), eluent water/acetonitrile with $0.1 \%$ acetic acid, flow rate $15 \mathrm{~mL} / \mathrm{min}$, chromatograph Agilent 1100 (Agilent Technologies, United States), detection by optical absorption of the eluent at a wavelength of $210 \mathrm{~nm}$, diode-array detector G1314A. The purity of the peptide preparation was confirmed by analytical HPLC with UV and mass spectrometric detection, a YMCTriart C18 column $(50 \times 2.1 \mathrm{~mm} \mathrm{LD}, S=1.9 \mu \mathrm{m})$, the column was thermostated at $30^{\circ} \mathrm{C}$, the volumetric flow rate of the mobile phase was $0.35 \mathrm{~mL} / \mathrm{min}$, a $0.1 \%$ solution of formic acid in water (eluent $\mathrm{A}$ ) and a $0.1 \%$ solution of formic acid in acetonitrile (eluent B) were used as the mobile phase; chromatographic separation of substances was carried out in the gradient elution mode: $0 \mathrm{~min}, 2 \% \mathrm{~B} ; 0-10 \mathrm{~min}$, linear gradient up to $100 \% \mathrm{~B} ; 10-12 \mathrm{~min}, 2 \% \mathrm{~B} ; t_{\mathrm{R}}=2.4 \mathrm{~min}$, mass spectrometer Agilent 6340 Ion Trap (Agilent Technologies, United States) with electrospray ionization, and the detector was an ion trap.

The peptide yield was $0.204 \mathrm{~g}$ ( $30 \%$ of theoretical); ESI-MS, $m / z$ : found $[\mathrm{M}+4 \mathrm{H}]^{4+} 680.5 ;[\mathrm{M}+5 \mathrm{H}]^{5+}$ $544.7 ; \quad[\mathrm{M}+6 \mathrm{H}]^{6+} 454.1 ;$ calculated $M_{r}$ $\left(\mathrm{C}_{124} \mathrm{H}_{216} \mathrm{~N}_{38} \mathrm{O}_{30}\right)$ 2719.3.

Determination of particle size in peptide solution. The peptide was dissolved in bidistilled water $(\mathrm{pH}$ 5.9) at a concentration of $0.5 \mathrm{mg} / \mathrm{mL}$, the particle size distribution was investigated, and the $\zeta$-potential was measured on a Zetasizer Nano ZS instrument (Malvern, United States) at $25^{\circ} \mathrm{C}$ using the Zetasizer Software. The experiment was repeated three times.

Enzyme-linked immunosorbent assay (ELISA). The study used blood serum samples from 84 patients infected with HCV (35 women and 49 men, average age 41 years), with a confirmed presence of antibodies to antigens NS4A and NS4B (according to the results of ELISA in the certified test system Best-anti-HCVspectrum, Vector-Best, Russia) were used in the study. As a control, blood samples from 10 healthy people 
with ut anti-HCV antibodies ( 5 woman and 5 men, mean age 35 years) were tested.

The peptide was immobilized in the wells of an immunological 96-well polystyrol plate with enhanced adsorption (Nunc, Denmark) at $4^{\circ} \mathrm{C}$ at a concentration of $10 \mu \mathrm{g} / \mathrm{mL}$ in a carbonate-bicarbonate buffer (pH 9.25) overnight. The free zones of the wells were blocked with a solution of bovine serum albumin $(1 \mathrm{mg} / \mathrm{mL}$; Sigma, United States) in phosphate-buffered saline ( $\mathrm{pH}$ 7.2). After that, blood serum samples diluted 10 times in phosphate-buffered saline with $0.1 \%$ Tween $20(\mathrm{pH} \mathrm{7.2)}$ were added to the wells, washed after incubation, and antipeptide immunoglobulins $\mathrm{G}$ were detected. The remaining ELISA steps were performed according to the generally accepted method [23].

Optical density was measured at a wavelength of $450 \mathrm{~nm}$ using a StatFax 3200 enzyme immunoassay microplate analyzer (photometer) (Awareness Technology Inc., United States). The cutoff absorbance value was calculated as the mean absorbance value of the negative control plus three standard deviations. The mean optical density of the negative control was 0.032 . The significance of differences in the detection of antibodies in the compared groups of patients was assessed by Student's $t$-test.

\section{CONCLUSIONS}

The 24-mer peptide VIVGRIILSGRPAVIPDREVLYRK-NH $\mathrm{N}_{2}$, the target part of which corresponds to the 24-46 amino acid fragment of nonstructural NS4A polypeptide HCV subtype $1 \mathrm{~b}$, was synthesized by solid-phase method. The target part of which corresponds to the 24-46 amino acid fragment of nonstructural NS4A polypeptide of HCV subtype $1 b$ (Fig. 1).

The immunoreactivity of the 24-mer peptide obtained was demonstrated via the interaction with blood sera of people infected with hepatitis $\mathrm{C}$ virus. It was found that $41.7 \%$ of blood sera of patients with antibodies to full-size antigens NS4A and NS4B contained immunoglobulins $G$ to the analyzed peptide. According to indirect evidence, the synthesized peptide contains an NS4A immunodominant B-epitope.

It was shown that this 24-mer peptide in the form of a highly purified aqueous preparation formed aggregates of a heterogeneous structure of small size and moderate stability. This indicates the ability of the peptide to bind to liposomes in the form of mediumsized particles $(\sim 200 \mathrm{~nm})$ and confirms its promising potential as a candidate for the construction of a lipopeptide immunogen against hepatitis $C$ virus.

\section{ACKNOWLEDGMENTS}

The authors are grateful to graduate students A.A. Yushina and V.A. Shchelkonogov (Lomonosov Institute of Fine
Chemical Technologies) for their assistance in determining the particle size and $\zeta$-potential of the peptide.

\section{FUNDING}

The study was financially supported by the Russian Foundation for Basic Research (project no. 19-33-90037).

\section{COMPLIANCE WITH ETHICAL STANDARDS}

This study was carried out in compliance with the ethical standards set out in the Declaration of Helsinki (1975, 2013). The patients gave informed consent for the use of their blood sera for research purposes. The study was approved by the Ethics Committee of the Russian Medical Academy of Continuing Professional Education of the Ministry of Health of Russia.

\section{Conflict of Interests}

The authors declare they have no conflict of interest.

\section{OPEN ACCESS}

This article is licensed under a Creative Commons Attribution 4.0 International License, which permits use, sharing, adaptation, distribution and reproduction in any medium or format, as long as you give appropriate credit to the original author(s) and the source, provide a link to the Creative Commons licence, and indicate if changes were made. The images or other third party material in this article are included in the article's Creative Commons licence, unless indicated otherwise in a credit line to the material. If material is not included in the article's Creative Commons licence and your intended use is not permitted by statutory regulation or exceeds the permitted use, you will need to obtain permission directly from the copyright holder. To view a copy of this licence, visit http://creativecommons.org/licenses/by/4.0/.

\section{REFERENCES}

1. Gonzalez-Aldaco, K., Torres-Reyes, L.A., OjedaGranados, C., Jose-Abrego, A., Fierro, N.A., and Roman, S., Ann. Hepatol., 2018, vol. 17, pp. 908-919. https://doi.org/10.5604/01.3001.0012.7191

2. Bailey, J.R., Barnes, E., and Cox, A.L., Gastroenterology, 2019, vol. 156, pp. 418-430.

https://doi.org/10.1053/j.gastro.2018.08.060

3. Chudinov, M.V., Fine Chem. Technol., 2019, vol. 14, pp. $7-23$. https://doi.org/10.32362/2410-6593-2019-14-4-7-23

4. Crouchet, E., Wrensch, F., Schuster, C., Zeisel, M.B., and Baumert, T.F., Ther. Adv. Gastroenterol., 2018, vol. 11, pp. 1-15. https://doi.org/10.1177/1756283X18759483

5. Brown, L.E. and Jackson, D.C., Curr. Drug Deliv., 2005, vol. 2, pp. 383-393.

https://doi.org/10.2174/156720105774370258 
6. Moisa, A.A. and Kolesanova, E.F., Biomed. Khim., 2011, vol. 57, pp. 14-30.

https://doi.org/10.18097/pbmc20115701014

7. Kolesanova, E.F., Sobolev, B.N., Moisa, A.A., Egorova, E.A., and Archakov, A.I., Biomed. Khim., 2015, vol. 61 , pp. $254-264$.

https://doi.org/10.18097/PBMC20156102254

8. Moisa, A.A. and Kolesanova, E.F., InTech: Rijeka, 2012, pp. 201-228.

https://doi.org/10.5772/2240

9. Baz, A., Buttigieg, K., Zeng, W., Rizkalla, M., Jackson, D.C., Groves, P., and Kelso, A., Vaccine, 2008, vol. 26 , pp. $2570-2579$.

https://doi.org/10.1016/j.vaccine.2008.03.022

10. BenMohamed, L., Gras-Masse, H., Tartar, A., Daubersies, P., Brahimi, K., Bossus, M., Thomas, A., and Druilhe, P., Eur. J. Immunol., 1997, vol. 27, p. 1242. https://doi.org/10.1002/eji.1830270528

11. Ivanov, B.B., Meshcheryakova, E.A., Andronova, T.M., and Ivanov, V.T., Russ. J. Bioorg. Chem., 1991, vol. 17, pp. 732-746.

12. Sobolev, B.N., Olenina, L.V., Kolesanova, E.F., Poroikov, V.V., and Archakov, A.I., Curr. Comp.-Aid. Drug Des., 2005, vol. 1, pp. 207-222. https://doi.org/10.2174/1573409053585681

13. Volpina, O.M., Titova, M.A., Zhmak, M.N., Koroev, D.O., Oboznaya, M.B., Volkova, T.D., and Ivanov, V.T., Russ. J. Bioorg. Chem., 2002, vol. 28, pp. 349-356.

14. Suzuki, T., Ishii, K., Aizaki, H., and Wakita, T., Adv. Drug Deliv. Rev., 2007, vol. 59, pp. 1200-1212. https://doi.org/10.1016/j.addr.2007.04.014

15. Gerlach, J.T., Ulsenheimer, A., Grüner, N.H., Jung, M.-C., Schraut, W., Schirren, C.-A., Heeg, M., Scholz, S., Witter, K., Zahn, R., Vogler, A., Zachoval, R., Pape, G.R., and Diepolder, H.M., J. Virol., 2005, vol. 19, pp. 12425-12433. https://doi.org/10.1128/JVI.79.19.12425-12433.2005

16. Pereboeva, L.A., Pereboev, A.V., and Morris, G.E., J. Med. Virol., 1998, vol. 56, pp. 105-111.

17. Wolk, B., Sansonno, D., Krausslich, H.G., Dammacco, F., Rice, C.M., Blum, H.E., and Moradpour, D., J. Virol., 2000, vol. 74, pp. 2293-2304.

18. Gu, M. and Rice, C.M., Curr. Opin. Virol., 2013, vol. 3, pp. 129-136.

https://doi.org/10.1016/j.coviro.2013.03.013

19. Dubuisson, J. and Cosset, F.-L., J. Hepatol., 2014, vol. 61, pp. 3-13.

https://doi.org/10.1016/j.jhep.2014.06.031

20. Hara, H., Aizaki, H., Matsuda, M., Shinkai-Ouchi, F., Inoue, Y., Murakami, K., Shoji, I., Kawakami, H., Matsuura, Y., Lai, M.M., Miyamura, T., Wakita, T., and Suzuki, T., J. Virol., 2009, vol. 83, pp. 5137-5147. https://doi.org/10.1128/jvi.02179-08

21. Campo, D.S., Dimitrova, Z., Mitchell, R.J., Lara, J., and Khudyakov, Y., Proc. Natl. Acad. Sci. U. S. A., vol. 105, pp. 9685-9690. https://doi.org/10.1073/pnas.0801774105

22. Desombere, I., Van Vlierberghe, H., Weiland, O., Hultgren, C., Sallberg, M., Quiroga, J., Carreno, V., and Leroux-Roels, G., J. Med. Virol., 2007, vol. 79, pp. $701-713$.

https://doi.org/10.1002/jmv.20846
23. Nikolaeva L.I., Makashova V.V., Petrova E.V., Shipulin G.A., Samokhvalov E.I., Tokmalaev A.K., L'vov D.K., Biomed. Khim., 2009, vol. 55, pp. 201212. https://doi.org/10.1134/S1990750809020127

24. Sarwar, M.T., Kausar, H., Ijaz, B., Ahmad, W., Ansar, M., Sumrin, A., Ashfaq, U.A., Asad, S., Gull, S., Shahid, I., and Hassan, S., Virol. J., 2011, vol. 8, p. 317. https://doi.org/10.1186/1743-422X-8-317

25. Chien, D.Y., McFarland, J., Tabrizi, A., Kuo, C., Houghton, M., and Kuo, G., in Viral Hepatitis and Liver Disease, Nishioka, K., Suzuki, H., Mishiro, S., and Oda, T., Eds., Tokyo: Springer, 1994, pp. 320-324.

26. Day, C.L., Lauer, G.M., Robbins, G.K., McGovern, B., Wurcel, A.G., Gandhi, R.T., Chung, R.T., and Walker, B.D., J. Virol., 2002, vol. 76, pp. 12584-12595. https://doi.org/10.1128/jvi.76.24.12584-12595.2002

27. Koroev, D.O., Volpina, O.M., Volkova, T.D., Kamynina, A.V., Samokhin, A.N., Filatova, M.P., and Bobkova, N.V., Russ. J. Bioorg. Chem., 2019, vol. 5, pp. 361365 . https://doi.org/10.1134/S1068162019050054

28. Aleshina, E.Yu., Pyndyk, N.V., Moisa, A.A., Sanzhakov, M.A., Kharybin, O.N., Nikolaev, E.N., and Kolesanova, E.F., Biomed. Khim., 2008. T. 54. S. 184-191. https://doi.org/10.1134/S1990750808030098

29. Kolesanova, E.F., Sanzhakov, M.A., and Kharybin, O.N., Int. J. Pept., 2013, vol. 2013, p. 197317. https://doi.org/10.1155/2013/197317

30. Nikolaeva, L.I., Kupriyanov, V.V., Leibman, E.A., Ionova, K.S., Samokhvalova, E.G., and Vasil'ev, A.V., in Materialy VII Ezhegodnogo Vserossiiskogo Kongressa po infektsionnym boleznyam s mezhdunarodnym uchastiem (Moskva, 30 marta-1 aprelya 2015 g.) (Proc. VII Annual All-Russia Congress on Infectious Diseases with International Participation, Moscow, March 30April 1, 2015), Moscow, 2015, p. 244.

31. Nikolaeva, L.I., Kupriyanov, V.V., Zykova, A.A., Ionova, K.S., and Ravin, N.V., V Mire Virus. Gepat., 2015, vols. $1-2$, pp. $12-17$.

32. Dobrynina A.V., Tsykunova M.A., Sebyakin Yu.L., Tonk. Khim. Tekhnol., 2010, vol. 5, pp. 98-103.

33. Varypataki, E.M., Benne, N., Bouwstra, J., Jiskoot, W., and Ossendorp, F., Cancer Immunol. Res., 2017, vol. 5, pp. $1-12$. https://doi.org/10.1158/2326-6066.CIR-16-0283

34. Tan, A.C.L., Mifsud, E.J., Zeng, W., Edenborough, K., McVernon, J., Brown, L.E., and Jackson, D.C., Mol. Pharm., 2012, vol. 9, pp. 2710-2718. https://doi.org/10.1021/mp300257x

35. Zeng, W., Eriksson, E., Chua, B.Y., Grollo, L., and Jackson, D., Amino Acids, 2010, vol. 39, pp. 471-480. https://doi.org/10.1007/s00726-009-0463-0

36. Langhans, B., Schweitzer, S., Nischalke, H.D., Braunschweiger, I., Sauerbruch, T., and Spengler, U., J. Infect. Dis., 2004, vol. 189, no. pp. 248-253. https://doi.org/10.1086/380763

37. Langhans, B., Braunschweiger, I., Schweitzer, S., Jung, G., Inchauspe, G., Sauerbrush, T., and Spengler, U., Immunology, 2001, vol. 102, pp. 460-465. https://doi.org/10.1046/j.1365-2567.2001.01209.x 